\title{
INTEGRANDO FRONTEIRAS NOS ESTUDOS ORGANIZACIONAIS
}

\author{
Por Rodrigo Hübner Mendes
}

Mestrando em Administração de Empresas pela FGV-EAESP.

E-mail: romendes@gvmail.br

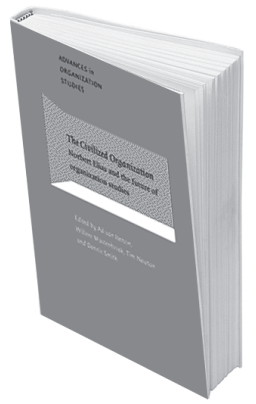

\section{THE CIVILIZED ORGANIZATIONS - NORBERT ELIAS AND THE FUTURE OF ORGANIZATION STUDIES}

De Ad van Iterson, Willem Mastenbroek, Tim Newton e Dennis Smith

Amsterdam/Philadelphia : John Benjamins, 2002. 251 p.
A área de estudos organizacionais tem sido marcada por um intenso crescimento, tanto em volume como em variedade de abordagens. Pesquisas interessadas em mapear essa abrangência de perspectivas revelam que, além de áreas temáticas tradicionais, como estratégia, tecnologia e processos, cinco novos agrupamentos têm direcionado a maioria das publicações: 1) redes; 2) poder, controle e resistência; 3) cultura, linguagem e conhecimento; 4) mudança; e 5) identidade, self e emoção.

The civilized organizations é um livro que, além de explorar esses novos agrupamentos em estudos organizacionais, busca estabelecer conexões entre eles e investigar suas raízes teóricas. Para isso, seus textos adotam como base referencial o trabalho de Norbert Elias (1897-1990), cuja obra vem sendo referência para um número crescente de estudos organizacionais. De acordo com seus autores, o trabalho de Elias destaca- se por sua capacidade de tratar temas tão diversos quanto "poder", "subjetividade" e "controle" sob a ótica de uma mesma estrutura conceitual.

O livro está organizado em quatro seções, cada uma composta por três capítulos. A primeira delas - "Organizando o discurso" - aborda questões relacionadas ao discurso organizacional, à gestão de emoções e às oscilações de poder derivadas de estruturas informais. No primeiro texto, Wilbert van Vree faz uma análise sobre uma das práticas mais comuns hoje nas organizações: as reuniões. Para tanto, desenvolve paralelos entre os estudos de Elias sobre a corte européia e o mundo contemporâneo, explorando as transformações pelas quais as reuniões têm passado ao longo do tempo e suas conseqüências para o processo decisório nas organizações. O autor mostra que as formas atuais de reuniões têm sua origem na metade do século XX, quando as tradicionais assembléias formais, cujas decisões se baseavam na vontade da maioria, começam a perder espaço para reuniões entre pequenos grupos, pautadas por códigos informais e pela busca de consenso.

O segundo capítulo examina a influência exercida pelos "boatos" no contexto organizacional. Seus autores, Joseph Soeters e Ad van Iterson, estabelecem uma diferenciação entre boatos positivos e negativos, relacionando a incidência de cada uma dessas formas ao tipo de cultura organizacional vigente. Organizações culturalmente homogêneas estariam propensas à presença de boatos positivos, enquanto ambientes heterogêneos tenderiam a propiciar boatos negativos.

No último texto da seção, Dennis Smith trabalha com o fator humilhação. Seus argumentos são desenvolvidos por meio de um modelo que categoriza as formas de humilhação e os tipos de organização em que esse fenômeno é observado com mais frequêencia. O capítulo é encer- 
rado com um estudo de caso que ilustra tais tipologias.

"Negociando fronteiras" é o título que abre a segunda seção do livro. Seus capítulos tratam das tensões e ambigüidades derivadas de processos sociais que transcendem as fronteiras da organização. No primeiro deles, Marja Gastelaars explora o tema privacidade e suas relações com algumas demandas da rotina organizacional contemporânea, como comprometimento e proatividade. O texto apresenta uma classificação dos estados da privacidade e examina as influências que o ambiente de trabalho exerce sobre a vida privada e a individualidade das pessoas.

No segundo texto, Ruud Stokvis busca estabelecer um entendimento sociológico das vantagens que os investidores têm tido em relação aos gestores nas últimas três décadas. Para explicar esse quadro, Stokvis analisa algumas tendências econômicas contemporâneas, como a expansão dos mercados, a abundância de recursos financeiros em busca de altos índices de rentabilidade e o poder de influência das empresas no mercado de ações.

Por fim, Tor Hernes revela a importância exercida pelas fronteiras internas e externas da organização em seus processos de transformação. De acordo com suas análises, zonas de fronteira devem ser consideradas um elemento-chave do jogo de poder do qual as organizações participam. Nelas são estabelecidos os contatos entre redes de interdependência e, conseqüentemente, os processos de negociações responsáveis pelo desenho dessas redes. O autor enfatiza, ainda, que indivíduos situados nessas zonas exercem alto poder de influência sobre as transformações por que passam as organizações.

$\mathrm{Na}$ terceira seção, denominada "Cruzando culturas", os autores exploram a influência que os aspectos culturais de uma nação exercem sobre o desenvolvimento das organizações, baseando-se em certos argumentos de Norbert Elias. No primeiro capítulo, Tatjana Globokar analisa as diferenças entre organizações francesas e alemãs. Esse contraste é apresentado como herança de padrões de comportamento da corte francesa e de certas tradições da burguesia alemã. Em seguida, Stephen Chen utiliza-se de alguns exemplos de empresas chinesas para revelar certas insuficiências das atuais tipologias de sistemas de negócio vigentes no Ocidente e na Ásia. Segundo ele, esses modelos são estáticos e simplistas, pois, ao mesmo tempo em que desconsideram a diversidade de organizações presente em cada região, negligenciam a importância de variáveis como "poder", "ideologia" e "interesses políticos" na configuração das estruturas de negócio.

A seção é concluída com um texto de Nidhi Srinivas, que explora o processo de replicação do modelo norteamericano de ensino na Índia. Para tanto, o autor faz referências à criação do IIG - Instituto Indiano de Gestão -, em 1959, e seus impactos na estrutura de negócios daquele país. Além de influenciar a formação da identidade das classes profissionais indianas, o IIG é apresentado como responsável por profundas transformações nessas mesmas classes.

$\mathrm{Na}$ quarta e última seção - "Teorizando a prática" -, os capítulos ilustram como as idéias de Norbert Elias podem colaborar para a reinterpretação das práticas organizacionais. No primeiro texto, Willem Mastenbroek explora o paradoxo entre liberdade de comportamento e aumento de controle. Segundo o autor, ao longo do tempo as redes de interdependência que permeiam as organizações foram adquirindo um grau crescente de complexidade, e tal processo teria colaborado para a cria- ção de padrões disciplinares mais intensos nas organizações modernas. $\mathrm{O}$ autor abre uma brecha para se entender os atuais modismos gerenciais à luz dessa evolução histórica das formas de controle.

O segundo texto, de Tim Newton, trata das relações entre a complexidade de processos ecológicos e a ordenação de redes organizacionais. O texto desenvolve uma análise crítica das atuais referências feitas às organizações "verdes". Segundo ele, as iniciativas voltadas à criação de uma nova ordem ecológica seriam demasiadamente audaciosas face à insuficiente atenção dada à complexidade envolvida nos projetos da área. O texto é concluído propondo novas perspectivas para pesquisas sobre as relações entre organizações e o meio ambiente.

No último capítulo, Mastenbroek aborda algumas das preocupações tradicionais da área de estudos organizacionais, como o dilema entre centralização e descentralização, investigando, por exemplo, as tensões existentes entre autonomia e interdependência. $\mathrm{O}$ autor mostra que a obra de Elias pode colaborar com valiosos insights sobre as formas pelas quais as organizações são estruturadas.

O livro traz importantes contribuições para leitores interessados em abordagens que rompem os paradigmas funcionalistas e positivistas ainda predominantes na literatura sobre organizações. A variedade de assuntos tratados oferece uma visão geral das novas tendências temáticas observadas nessa literatura. Além disso, seus autores sugerem inter-relações provocativas entre as análises recentemente publicadas sobre esses temas. O livro também mostra como a obra de Norbert Elias - autor ainda pouco explorado por certas ciências sociais - pode ter uma variedade tão grande de aplicações nos estudos organizacionais. 